\title{
Paddock Size and Stocking Density Affect Spatial Heterogeneity of Grazing
}

\author{
Matthew K. Barnes, ${ }^{1}$ Brien E. Norton, ${ }^{2}$ Motoko Maeno, ${ }^{3}$ and John C. Malechek ${ }^{4}$
}

Authors are ${ }^{1}$ Rangeland Management Specialist, USDA Natural Resources Conservation Service, Kremmling, CO 80459, USA; ${ }^{2}$ Director, Centre for the Management of Arid Environments, PMB 22, Kalgoorlie, WA 6433, Australia, and Emeritus Associate Professor, Department of Wildland Resources, Utah State University, Logan, UT 84322, USA $;^{3}$ deceased; and ${ }^{4}$ Professor, Department of Wildland Resources, Utah State University, Logan, UT 84322, USA.

\begin{abstract}
The claim that intensive rotational grazing (IRG) can sustain higher stocking rates can be partially explained by more even spatial distribution of grazing such that livestock consume forage from a greater proportion of a pasture. To test the hypothesis that utilization is more even at the higher stocking densities of smaller paddocks, mean absolute deviation (heterogeneity) of utilization estimates by plot was compared in paddocks of sizes and stocking densities representing increasing subdivision from two-paddock deferred rotation grazing (DRG) to 16-, 32-, and 64-paddock, two-cycle IRG. These 70-, 4-, 2-, and 1-ha paddocks were grazed for $7 \mathrm{wk}, 4 \mathrm{~d}, 2 \mathrm{~d}$, and $1 \mathrm{~d}$, respectively, at 32 animal unit days (AUD) $\cdot \mathrm{ha}^{-1}$ during 2000 and 34 AUD $\cdot \mathrm{ha}^{-1}$ during 2001. Within IRG there was no response to the treatment gradient. After one cycle in the IRG paddocks, heterogeneity of use was generally lower than in the DRG paddocks, in both 2000 (3-11\% [outlier 18\%] vs. 14-19\%) and 2001 (9-17\% vs. $24-28 \%)$. After a second cycle in 2001 , heterogeneity in half of the IRG paddocks (17-21\%) was nearly as high as the early-grazed $(24 \%)$, but not the late-grazed $(28 \%)$, of the DRG paddocks. This lack of a stronger difference between systems was probably due to the fixed two-cycle IRG schedule and lack of plant growth during the nongrazing interval. Across both systems heterogeneity of utilization was strongly positively correlated with paddock size. Because utilization was not severely patchy in the largest treatment, the difference between systems would likely be greater in commercial-scale paddocks. Thus grazing distribution can be more even under intensive than extensive management, but this depends on how adaptively the system, particularly the aspects of timing and frequency, is managed.
\end{abstract}

\section{Resumen}

La afirmación de que el pastoreo rotacional intensivo (PRI) logra mantener una mayor carga animal se puede explicar parcialmente a que existe una distribución más uniforme del pastoreo de tal manera de que el ganado consume forraje de la mayoría del potrero. Para probar la hipótesis que la utilización es más homogénea en potreros pequeños con una mayor densidad animal, la absoluta desviación de la media (heterogeneidad) de la utilización estimada, se comparó en potreros de diferentes tamaños y densidades de cargas representando un incremento en las sub-divisiones utilizando un sistema de pastoreo de rotación diferida (PRD). Se utilizaron 2 potreros en el PRD y 16, 32 y 64 potreros, en el pastoreo rotacional intensivo (PRI) de 2 ciclos. Estos potreros de 70, 4, 2, y 1 hectárea fueron pastoreados durante 7 semanas, 4 días, 2 días y 1 día respectivamente con 23 unidades animal-días (UAD) $\cdot \mathrm{ha}^{-1}$ durante 2000 y $34 \mathrm{UAD} \cdot \mathrm{ha}^{-1}$ durante 2001. Dentro del PRI no se encontró respuesta entre tratamientos. Después de un ciclo en los potreros de PRI, la heterogeneidad de uso fue generalmente menor que en los potreros del PRD, tanto en 2000 (3-11\% [afuera 18\%] vs. 14-19\%) y en 2001 (9-17\% vs. 24-28\%). Después del segundo ciclo en 2001, la heterogeneidad (17-21\%) en la mitad de los potreros de PRI fue muy similar a la presentada al inicio del pastoreo (24\%), pero diferente al final del pastoreo ( $28 \%$ ), de los potreros del PRD. El que no se hayan encontrado diferencias entre sistemas de pastoreo fue posiblemente debido a los 2 ciclos fijos programados del PRI y a la falta de crecimiento de las plantas durante el intervalo de descanso. A través de ambos sistemas, la heterogeneidad de la utilización mantuvo una estrecha y positiva correlación con el tamaño del potrero. Debido a que la utilización no fue totalmente heterogénea en el tratamiento con el potrero más grande, las diferencias entre sistemas posiblemente podrían ser mayores en sistemas a escala comercial. Por lo tanto, la distribución del pastoreo puede ser más uniforme bajo condiciones intensivas que la que pueda darse en condiciones extensivas, pero esto depende de la adaptabilidad del sistema, en particular si los aspectos de tiempo y frecuencia se manejan adecuadamente.

Key Words: deferred rotation grazing, grazing management systems, intensive rotational grazing, livestock distribution, short duration grazing, time control grazing

In memory of Motoko Maeno.

This research was supported by the Utah Agricultural Experiment Station, Utah State University, Logan, UT 84322, USA. Approved as journal paper 7806.

At the time of the research, Barnes and Maeno were graduate research assistants and Norton was Associate Professor, Dept of Forest, Range, and Wildlife Sciences, Utah State University, Logan, UT, USA.

Correspondence: Matthew K. Barnes, PO Box 552, Kremmling, CO 80459, USA. Email: mattk.barnes@gmail.com

Manuscript received 15 November 2006; manuscript accepted 29 February 2008.

\section{INTRODUCTION}

Intensive rotational grazing (IRG) has been advocated as widely applicable for restoring rangeland productivity, but some in the rangeland science community have denounced it (Holechek et al. 2000). The approach is designed to control frequency of defoliation and prevent forage from becoming overmature (Savory with Butterfield 1999), such that livestock nutrition and therefore performance presumably are not 
diminished (Kothmann 1980, 1984). In this paper the term IRG is used to cover all variations, whether the length of grazing and nongrazing periods is controlled by plant growth rates (time control or short duration grazing [SDG]) or is calendar-based, but does not include high-intensity-low-frequency grazing (which entails significantly heavier use and longer grazing and nongrazing periods).

Practitioners of IRG have claimed dramatic increases in livestock carrying capacity, often on the order of double the stocking rate used with continuous grazing (CG), with simultaneous improvement in rangeland resources (Savory and Parsons 1980; Cumming 1989; Earl and Jones 1996; Bradford 1998; Savory with Butterfield 1999; Sayre 2000; Gordon 2002). However, most reviews of grazing studies have concluded that IRG is no better than traditional extensive grazing management, and sometimes worse for livestock production (Gammon 1978; Pieper 1980; Heitschmidt and Taylor 1991; Holechek et al. 2000; Vallentine 2001; Briske et al. 2008). A few researchers have concluded that a slightly higher long-term stocking rate can be sustained under IRG than extensive management (Gammon 1984; Wilson 1986; Heitschmidt et al. 1987; Bryant et al. 1989; Joseph et al. 2002), but probably not enough of an increase to justify costs. Currently, some in the research community see little benefit from more complex approaches than CG and conservative stocking (Holechek et al. 1999, 2000; Galt et al. 2000). The evidence in favor of IRG is largely anecdotal, and the opposing perspective is well established in the research literature and textbooks.

Norton $(1998,2003)$ hypothesized that the paradigm of rotational grazing to control the frequency of defoliation is limited, and that a broader framework emphasizing spatial distribution is necessary. Grazing distribution is heterogeneous, especially in large paddocks on extensively managed arid, semiarid, and mountainous rangelands (Coughenour 1991; Bailey et al. 1996). Previously grazed plants are likely to be grazed again as the growing season progresses (O'Connor 1992), and areas grazed in previous years are more heavily grazed in subsequent years (Ganskopp and Bohnert 2006); this patch or spot grazing in large, extensively grazed paddocks has been identified as a mechanism of rangeland degradation even at low stocking rates (Ring et al. 1985; Willms et al. 1988; Fuls 1992). This phenomenon has been minimized in grazing studies involving unrealistically small paddocks, where no advantage to IRG was observed (Norton 1998). As evidence that paddock size influences grazing capacity, Norton's table 1 lists nine examples from around the world where stocking rates on research stations have been sustained at $50-100 \%$ greater than the recommended rates for the localities for many years without degradation, even in CG paddocks (p. 21).

Most studies on research stations that explicitly addressed grazing distribution have reported little or no advantage to IRG over more extensive management (Kirby et al. 1986; Hacker et al. 1988; Walker et al. 1989; Burboa-Cabrera et al. 2003). Hart et al. $(1989,1993 a)$ found that distribution was more even in 24-ha paddocks, with CG or SDG, than a 207-ha CG paddock; and there was little difference in frequency or intensity of tiller defoliation between CG and SDG in 9- and 12-ha paddocks (Hart et al. 1993b). However, at the Jornada Experimental Range in the Chihuahuan Desert, grazing was more uniform in a 34.7-ha, 10-paddock cell when the rotation was flexible according to growth rate and light utilization than when it was calendar-based, or than in a 33.6-ha paddock grazed season-long at lower stocking density (Anderson 1988). Bryant et al. (1989) stated that in a study near Plains, Texas, distribution was improved with IRG in relatively large paddocks (180- and 260ha cells, each with six paddocks) such that higher stocking rates could be maintained, but noted that standing crop increased with distance from water in another SDG cell (Soltero et al. 1989) and concluded that "doubt has been cast on the theory that [SDG] improves animal distribution" (p. 296).

In contrast to the above studies, Teague and Dowhower (2003) examined the ability of rotational grazing to reduce degradation caused by patch-selective grazing in large (1 800 $2100 \mathrm{ha}$ ) paddocks in the rolling plains of Texas. The eightpaddock rotation increased herbaceous basal cover and decreased bare ground relative to CG. Both treatments exhibited improvement during favorable growing conditions, but the improvements were significantly greater in the rotational grazing treatment, where there was also less deterioration during drought (Teague et al. 2004). A ranchscale study in New South Wales, Australia, found increased basal cover and improved species composition in SDG cells relative to adjacent CG paddocks after only $2 \mathrm{yr}$ (Earl and Jones 1996); and in the Flooding Pampas of Argentina operations that changed from CG to SDG had increased litter, decreased bare ground, and improved species composition relative to adjacent operations still using CG (Jacobo et al. 2006).

If animal distribution can be made more even with highdensity grazing, such that more forage is encountered and thus made available to livestock, patch grazing is minimized or eliminated, and selectivity is reduced, then the sustainable stocking rate will be higher under IRG management. This would explain much of the debate between researchers and practitioners. Thus, the specific objective of this study was to test the null hypothesis that the spatial distribution of utilization, as indexed by heterogeneity of variance, would be unaffected by a gradient of paddock size and stocking density, representing increasing landscape subdivision under IRG relative to more extensive grazing management.

\section{METHODS}

\section{Study Site}

The field research was done at the Utah Agricultural Experiment Station site southeast of Miner's Peak on Cedar Mountain, at the boundary of Washington and Iron Counties, Utah, USA (lat $37^{\circ} 30^{\prime} \mathrm{N}$, long $113^{\circ} \mathrm{W}$ ). The site is at a mean elevation of about $2600 \mathrm{~m}$, on the Kolob Terrace above the Grey Cliffs formation. Soils are classified as fine-loamy, mixed, superactive, frigid Pachic Haplustolls, 4-15\% slopes (Sheckle series); and fine, smectitic, frigid Pachic Argiustolls, 0-65\% slopes (Fughes series). Precipitation averages about $760 \mathrm{~mm}$, in a bimodal pattern with peaks as winter snow and late summer thunderstorms.

The vegetation is a mosaic of mountain meadows with woodlands of quaking aspen (Populus tremuloides Michx.) and Gambel oak (Quercus gambelii Nutt.) and patches of mountain 
Table 1. Amount and heterogeneity of forage and utilization in paddocks representing a gradient of two-cycle intensive rotational grazing (IRG) intensity and in deferred rotation grazing (DRG) paddocks during two grazing seasons. Data for IRG in 2000 and the first cycle in 2001 are for half of a season, while data for the second cycle in 2001 and DRG are for a full season of use.

\begin{tabular}{|c|c|c|c|c|c|c|c|c|c|c|c|}
\hline \multirow{2}{*}{$\begin{array}{l}\text { Grazing } \\
\text { system }\end{array}$} & \multirow{2}{*}{$\begin{array}{l}\text { Size } \\
\text { (ha) }\end{array}$} & \multirow{2}{*}{$\begin{array}{c}\text { Stocking } \\
\text { density ratio }{ }^{1}\end{array}$} & \multirow{2}{*}{$\begin{array}{l}\text { Paddock } \\
\text { identifier }\end{array}$} & \multirow[b]{2}{*}{ Start date } & \multirow[b]{2}{*}{ End date } & \multicolumn{3}{|c|}{ Available forage } & \multicolumn{3}{|c|}{ Utilization } \\
\hline & & & & & & $n$ & Mean $^{2}$ & Heterogeneity ${ }^{2,3}$ & $n$ & Mean $^{2}$ & Heterogeneity ${ }^{2,3}$ \\
\hline Summer 2000 & & & & & & & - & $\left.g \cdot m^{-2}\right)-$ & & 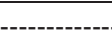 & (\%) ------ \\
\hline \multirow[t]{6}{*}{ IRG (cycle 1) } & 1 & 64 & A & 17 July & 18 July & 18 & $160 \mathrm{a}$ & $61 \mathrm{ab}$ & 97 & $13 \mathrm{de}$ & $8 d$ \\
\hline & & & B & 17 Aug. & 18 Aug. & 25 & $99 \mathrm{bc}$ & $21 \mathrm{~b}$ & 89 & $23 \mathrm{~b}$ & $18 \mathrm{a}$ \\
\hline & 2 & 32 & A & 18 July & 20 July & 25 & $110 a b$ & $23 \mathrm{~b}$ & 189 & $12 \mathrm{e}$ & $5 \mathrm{e}$ \\
\hline & & & B & 15 Aug. & 17 Aug. & 25 & $73 d$ & $28 \mathrm{~b}$ & 189 & $17 \mathrm{bcd}$ & $11 \mathrm{c}$ \\
\hline & 4 & 16 & A & 28 July & 1 Aug. & 25 & $77 \mathrm{~cd}$ & $100 \mathrm{a}$ & 375 & $11 \mathrm{e}$ & $3 \mathrm{e}$ \\
\hline & & & B & 1 Aug. & 5 Aug. & 25 & $82 \mathrm{~cd}$ & $28 \mathrm{~b}$ & 384 & $16 \mathrm{~cd}$ & $10 \mathrm{~cd}$ \\
\hline \multirow[t]{2}{*}{ DRG } & 70 & 2 & A & 12 June & 9 Aug. & - & - & - & 276 & $21 \mathrm{bc}$ & $19 \mathrm{a}$ \\
\hline & & & B & 9 Aug. & 12 oct. & - & - & - & 256 & $56 \mathrm{a}$ & $14 \mathrm{~b}$ \\
\hline \multicolumn{12}{|l|}{ Summer 2001} \\
\hline \multirow[t]{7}{*}{ IRG (cycle 1) } & 1 & 64 & B & 29 June & 30 June & 20 & $110 a b$ & $46 \mathrm{ab}$ & 89 & $17 \mathrm{~cd}$ & $14 \mathrm{c}$ \\
\hline & & & C & 3 July & 4 July & 20 & $73 \mathrm{~b}$ & $35 \mathrm{ab}$ & 90 & $20 \mathrm{~cd}$ & $17 \mathrm{c}$ \\
\hline & & & A & 6 July & 7 July & 20 & $130 \mathrm{a}$ & $8 \mathrm{c}$ & 96 & $16 \mathrm{~cd}$ & $13 \mathrm{~cd}$ \\
\hline & 2 & 32 & B & 27 June & 29 June & 20 & $130 \mathrm{a}$ & $7 \mathrm{c}$ & 185 & $20 \mathrm{c}$ & $15 \mathrm{c}$ \\
\hline & & & A & 9 July & 11 July & 20 & $110 a b$ & $24 \mathrm{bc}$ & 186 & $14 \mathrm{~d}$ & $9 d$ \\
\hline & 4 & 16 & B & 29 June & 3 July & 20 & $110 a b$ & $50 \mathrm{a}$ & 387 & $20 \mathrm{c}$ & $17 \mathrm{c}$ \\
\hline & & & A & 2 July & 6 July & 20 & $100 \mathrm{ab}$ & $46 \mathrm{ab}$ & 375 & $17 \mathrm{~cd}$ & $14 \mathrm{c}$ \\
\hline \multirow[t]{2}{*}{ DRG } & 70 & 2 & B & 15 June & 9 Aug. & - & - & - & 248 & $30 \mathrm{bC}$ & $24 \mathrm{bB}$ \\
\hline & & & A & 9 Aug. & 14 Oct. & - & - & - & 199 & $41 \mathrm{aAB}$ & $28 \mathrm{aA}$ \\
\hline \multirow[t]{6}{*}{ IRG (cycle 2) } & 1 & 64 & c & 5 Sep. & 6 Sep. & 20 & $47 \mathrm{~b}$ & $13 b$ & 90 & $42 \mathrm{~A}$ & $19 \mathrm{CD}$ \\
\hline & & & A & 5 Sep. & 6 Sep. & 20 & $100 \mathrm{a}$ & $55 \mathrm{a}$ & 96 & $31 \mathrm{BC}$ & $21 \mathrm{BC}$ \\
\hline & 2 & 32 & B & 30 Aug. & 1 Sep. & 20 & $65 a b$ & $14 \mathrm{~b}$ & 185 & $34 \mathrm{ABC}$ & $17 \mathrm{D}$ \\
\hline & & & A & 6 Sep. & 8 Sep. & 20 & $85 a b$ & $69 a$ & 186 & $36 \mathrm{ABC}$ & $21 \mathrm{BC}$ \\
\hline & 4 & 16 & B & 1 Sep. & 5 Sep. & 20 & $67 a b$ & $25 \mathrm{~b}$ & 386 & $40 A B$ & $20 \mathrm{CD}$ \\
\hline & & & A & 1 Sep. & 5 Sep. & 20 & $51 a b$ & $23 \mathrm{~b}$ & 375 & $38 \mathrm{AB}$ & $21 \mathrm{BC}$ \\
\hline
\end{tabular}

${ }^{1}$ Stocking density $\cdot$ stocking rate ${ }^{-1}$, or the number of paddocks in the rotation if paddock sizes are equal.

${ }^{2}$ Within columns and grazing cycles, including DRG, means followed by the same letter are not significantly different $(P<0.05)$; uppercase letters compare DRG and cycle 2 IRG.

${ }^{3}$ Mean absolute value of deviations of quadrat estimates from their paddock means.

snowberry (Symphoricarpos oreophilus var. oreophilus Gray). The herbaceous layer is dominated by Kentucky bluegrass (Poa pratensis L.), Letterman needlegrass (Achnatherum lettermanii [Vasey] Barkworth), slender wheatgrass (Elymus trachycaulus subsp. trachycaulus [Link] Gould ex Shinners), mountain brome (Bromus marginatus Nees ex Steud.), Arizona mulesear (Wyethia arizonica Gray), and tarweed (Madia glomerata Hook.). The vegetation was apparently converted from tall forb dominance to grass, mulesear, and tarweed dominance by a history of heavy CG by sheep (Bowns and Bagley 1986). Native herbivores that use the area include grasshoppers (order Orthoptera), pocket gophers (Thomomys bottae Eydoux and Gervais), mule deer (Odocoileus hemionus hemionus Rafinesque), and Rocky Mountain elk (Cervus elaphus nelsoni Bailey). The site is fenced into paddocks of about 70 ha each, which are grazed in two-paddock deferred rotations from late June through early October.

\section{Grazing Treatments}

Treatments imposed a gradient of decreasing paddock size and increasing stocking density, representing increasing landscape subdivision (Table 1). Treatments represented stocking densities that would occur in 16-, 32-, and 64-paddock rotations with two 64-d grazing cycles per 4-mo grazing season. The IRG paddock sizes were 4 ha, 2 ha, and 1 ha; these were grazed for $4 \mathrm{~d}, 2 \mathrm{~d}$, and $1 \mathrm{~d}$, respectively. The study was conducted during 2 yr: in 2000 each IRG paddock was grazed only once because the grazing periods were too late in the season (between 17 July and 18 August) to be followed by the second cycle, and in 2001 each was grazed twice with a 2 -mo interval between grazing periods (between 29 June and 11 July, and between 30 August and 8 September). There were two paddocks of each treatment, with the exception that there were three 1-ha paddocks during the first grazing cycle in 2001. Stocking rate was held constant across all treatments within each year and was the same rate used on the rest of the site, as determined by the site manager (based on winter snowpack and a 50\% utilization target): 32 animal unit days (AUD) $\cdot \mathrm{ha}^{-1}$ during 2000, and 34 AUD $\cdot$ ha $^{-1}$ during 2001. During 2000 one herd of 16 cowcalf pairs grazed each IRG paddock; thus the actual stocking densities in these treatments were 4,8 , and $16 \mathrm{AU} \cdot \mathrm{ha}^{-1}$. During 2001 two herds of 16 cow-calf pairs and one bull were used simultaneously for IRG, with each herd grazing one paddock of each of the three treatments in both grazing periods (except when there were three 1-ha paddocks during the first cycle of 2001); stocking densities were 4.25, 8.5, and 17 $\mathrm{AU} \cdot \mathrm{ha}^{-1}$. Utilization in a pair of deferred rotation grazing 
(DRG) paddocks (each grazed for half of each season) was also sampled each year. The number of animals in these paddocks was double that of the IRG paddocks to maintain the same stocking rate; the stocking density was $0.46 \mathrm{AU} \cdot \mathrm{ha}^{-1}$ in 2000 and $0.49 \mathrm{AU} \cdot \mathrm{ha}^{-1}$ in 2001.

IRG paddocks were constructed with steel corner posts and temporary electric fencing ( $8 \mathrm{kV}$ tape). Layout and initial construction of six paddocks were done in 2000 , and corner posts were left in place so that the same paddocks could be used in 2001. However, one of the 1-ha paddocks (B) could not be used during the second cycle in 2001 (because of conflict with other uses of the site), so another 1-ha paddock (C) was established and then used in both cycles. The IRG paddocks were located so as to contain as similar vegetation as possible, in rolling topography, and to avoid deep gullies or large patches of Arizona mulesear that contained little or no grass. A water trough and trace mineralized salt block were located together near the fence on one side of each IRG paddock. Deferred rotation paddocks necessarily contained more topographic variation due to their size, and had stock ponds in drainage bottoms and salt blocks placed on uplands.

The cows had grazed the area during previous years and thus were familiar with the study area. Most of the cows used in 2000 remained in the herd in 2001. The cattle used in the IRG trials were acclimated to the study area for about $1 \mathrm{wk}$ and were kept in a 2-ha training area where they were familiarized with small paddock size, high stocking density, and the electric fence for $2 \mathrm{~d}$ prior to the first trial in each year. Cattle spent the rest of the year on Great Basin desert rangeland or farmland; calves were born off-site in the spring, and weaned and sold in the fall. Breeds included Hereford and crosses of Hereford, Angus, Charolais, and Simmental.

\section{Data Collection}

All aboveground herbaceous plant biomass and shrub foliage below $50 \mathrm{~cm}$ from ground level was considered available and was measured in each IRG paddock, $<24 \mathrm{~h}$ prior to each grazing period, by the weight-estimate method (Pechanec and Pickford $1937 \mathrm{~b}$ ) using $0.25-\mathrm{m}^{2}$ quadrats at $18-25$ points on randomly located line transects. Growth during the short grazing periods of IRG was negligible and very unlikely to affect grazing distribution, in contrast to the much longer grazing periods of DRG.

Distribution of grazing, as the response variable of interest, was measured more intensively than available forage (which was measured only in IRG paddocks). It was assessed after each grazing period by systematic sampling of forage utilization on a $10 \times 10 \mathrm{~m}$ grid covering each IRG paddock, and a $60 \times 60 \mathrm{~m}$ grid covering each DRG paddock. Grids were anchored to a paddock corner, with gridlines perpendicular to the longest fence line. Distances between gridlines were measured and marked along fenced perimeters, while distances between gridpoints in the interiors of paddocks were paced; thus paddock coverage of samples was similar for each assessment, but relocation of quadrats in successive periods was approximate. Utilization was assessed by ocular estimate in a $0.25-\mathrm{m}^{2}$ quadrat at each gridpoint in the IRG paddocks and in a $1-\mathrm{m}^{2}$ quadrat at each gridpoint in the DRG paddocks, the larger quadrat intended to offset the reduction of sampling intensity due to the coarser grid. Use was assigned to one of five classes: unused, $<20 \%, 20-40 \%, 40-60 \%$, and $60-80 \%$. During 2001 the method was refined by correcting utilization estimates for observer bias with estimates of clipped and weighed plots (Pechanec and Pickford 1937a).

\section{Data Analysis}

Because of differences in initial species composition (Maeno 2002), time of season when grazed, and forage availability, paddocks of the same size and stocking density were unsuitable as replicates and thus were analyzed separately. Quadrats served as the experimental units; that is, means were calculated for each paddock, rather than across paddocks of the same grazing treatment, increasing the sample sizes and degrees of freedom. Consequently the inference space is limited to the paddocks in this study.

The mean absolute deviation (the mean of the absolute values of the deviations of the quadrat estimates from their paddock means, and the variance metric in Levene's test for homogeneity of variance) is an index of spatial heterogeneity. To assess relative initial uniformity within paddocks, heterogeneity of variance in available forage was analyzed for each grazing cycle with Levene's test; Tukey's studentized range test was used for pairwise comparisons of paddock variances using PROC GLM of SAS (1999). Available forage means were analyzed for differences among the IRG paddocks using an analysis of variance of a one-way factorial in a completely randomized design, with a heterogeneous variances model, such that a separate variance was estimated for each paddock. Computations were done using PROC MIXED of SAS (1999) and pairwise mean comparisons were Tukey-Kramer adjusted.

All utilization estimates were converted to the midpoint of the recorded class $(0,0.1,0.3,0.5$, or 0.7$)$ for analysis. Correction factors for observer bias in 2001 were small (0.901.16). Intensity and heterogeneity of utilization were analyzed with the same statistical methods as used for available forage. Because quadrat estimates were the experimental units, and there were $89-387$ in each paddock, the degrees of freedom were 1757-1 846 for each grazing cycle.

Pearson's correlation coefficients were calculated to assess relative importance of potential explanatory variables for amount and heterogeneity of available forage and utilization (Table 2). For IRG paddocks, means and mean absolute deviations of available forage and utilization were analyzed for correlation with each other and with timing (the middle day of each grazing period, counted from the first day of the grazing season), as well as paddock size and stocking density. The same correlations were done including both IRG and DRG, only without the forage availability variables or first cycle IRG mean utilization, because it was not comparable to that in the DRG paddocks.

\section{RESULTS}

\section{Summer 2000}

There were significant differences between the six IRG paddocks in amounts of initial forage available (Table $1 ; F_{5,137}$ $=3.50, P=0.0052)$ and heterogeneity thereof $\left(F_{5,137}=7.86\right.$, $P<0.0001)$. There were also significant differences between 
Table 2. Correlation coefficients and probability levels for amount and heterogeneity of forage and utilization in paddocks representing a gradient of two-cycle intensive rotational grazing (IRG) intensity and for heterogeneity of utilization including deferred rotation grazing (DRG) paddocks during two grazing seasons. Data for IRG in 2000 and the first cycle in 2001 are for half of a season, while data for the second cycle in 2001 and DRG are for a full season of use.

\begin{tabular}{|c|c|c|c|c|c|c|c|c|}
\hline & \multicolumn{4}{|c|}{ Available forage } & \multicolumn{4}{|c|}{ Utilization } \\
\hline & \multicolumn{2}{|c|}{ Mean } & \multicolumn{2}{|c|}{ Heterogeneity ${ }^{1}$} & \multicolumn{2}{|c|}{ Mean } & \multicolumn{2}{|c|}{ Heterogeneity ${ }^{1}$} \\
\hline & $r$ & $P$ & $r$ & $P$ & $r$ & $P$ & $r$ & $P$ \\
\hline \multicolumn{9}{|l|}{ Summer 2000} \\
\hline \multicolumn{9}{|l|}{ IRG (cycle 1) only $(n=6)$} \\
\hline Available forage mean & - & - & 0.04 & 0.9359 & -0.17 & 0.7458 & -0.08 & 0.8847 \\
\hline Heterogeneity & 0.04 & 0.9359 & - & - & -0.60 & 0.2083 & -0.55 & 0.2634 \\
\hline Utilization mean & -0.17 & 0.7458 & -0.60 & 0.2083 & - & - & 0.98 & 0.0004 \\
\hline Heterogeneity & -0.08 & 0.8847 & -0.55 & 0.2634 & 0.98 & 0.0004 & - & - \\
\hline Timing (middle date) & -0.20 & 0.7030 & -0.28 & 0.5939 & 0.30 & 0.5653 & 0.14 & 0.7884 \\
\hline Size & -0.64 & 0.1742 & 0.41 & 0.4180 & -0.43 & 0.3946 & -0.46 & 0.3622 \\
\hline Stocking density & 0.72 & 0.1077 & 0.24 & 0.6408 & 0.49 & 0.3220 & 0.55 & 0.2579 \\
\hline \multicolumn{9}{|l|}{ IRG (cycle 1) and DRG $(n=8)$} \\
\hline Utilization mean & - & - & - & - & - & - & 0.50 & 0.2024 \\
\hline Timing (middle date) & - & - & - & - & - & - & 0.02 & 0.9573 \\
\hline Size & - & - & - & - & - & - & 0.56 & 0.1514 \\
\hline Stocking density & - & - & - & - & - & - & -0.05 & 0.9039 \\
\hline \multicolumn{9}{|l|}{ Summer 2001} \\
\hline \multicolumn{9}{|l|}{ IRG (cycle 1) only $(n=7)$} \\
\hline Forage mean & - & - & -0.54 & 0.2093 & -0.25 & 0.5893 & -0.35 & 0.4467 \\
\hline Heterogeneity & -0.54 & 0.2093 & - & - & 0.17 & 0.7219 & 0.35 & 0.4389 \\
\hline Utilization mean & -0.25 & 0.5893 & 0.17 & 0.7219 & - & - & 0.94 & 0.0018 \\
\hline Heterogeneity & -0.35 & 0.4467 & 0.35 & 0.4389 & 0.94 & 0.0018 & - & - \\
\hline Timing (middle date) & -0.63 & 0.1315 & 0.33 & 0.4687 & -0.49 & 0.2594 & -0.47 & 0.2838 \\
\hline Size & 0.02 & 0.9633 & 0.50 & 0.2575 & 0.17 & 0.7115 & 0.17 & 0.7078 \\
\hline Stocking density & -0.15 & 0.7501 & -0.27 & 0.5527 & -0.09 & 0.8414 & 0.02 & 0.9683 \\
\hline \multicolumn{9}{|l|}{ IRG (cycle 1$)$ and DRG $(n=9)$} \\
\hline Utilization mean & - & - & - & - & - & - & 0.97 & $<0.0001$ \\
\hline Timing (middle date) & - & - & - & - & - & - & 0.75 & 0.0196 \\
\hline Size & - & - & - & - & - & - & 0.90 & 0.0010 \\
\hline Stocking density & - & - & - & - & - & - & -0.59 & 0.0924 \\
\hline \multicolumn{9}{|l|}{ IRG (cycle 2) only $(n=6)$} \\
\hline Cycle 2 available forage mean & - & - & 0.85 & 0.0335 & -0.82 & 0.0440 & 0.45 & 0.3680 \\
\hline Heterogeneity & 0.85 & 0.0335 & - & - & -0.53 & 0.2847 & 0.66 & 0.1520 \\
\hline Cycle 1 available forage mean & 0.72 & 0.1061 & 0.37 & 0.4718 & -0.86 & 0.0274 & -0.06 & 0.9162 \\
\hline Heterogeneity & -0.58 & 0.2285 & -0.33 & 0.5223 & 0.82 & 0.0442 & 0.34 & 0.5086 \\
\hline Cumulative utilization mean & -0.82 & 0.0440 & -0.53 & 0.2847 & - & - & -0.07 & 0.8992 \\
\hline Heterogeneity & 0.45 & 0.3680 & 0.66 & 0.1520 & -0.07 & 0.8992 & - & - \\
\hline Cycle 1 utilization mean & -0.68 & 0.1369 & -0.91 & 0.0119 & 0.48 & 0.3329 & -0.74 & 0.0934 \\
\hline Heterogeneity & -0.65 & 0.1654 & -0.88 & 0.0218 & 0.53 & 0.2748 & -0.49 & 0.3200 \\
\hline Cycle 2 timing (middle date) & 0.38 & 0.4627 & 0.70 & 0.1186 & 0.07 & 0.8961 & 0.70 & 0.1243 \\
\hline Size & -0.31 & 0.5539 & -0.25 & 0.6274 & 0.34 & 0.5099 & 0.21 & 0.6850 \\
\hline Stocking density & 0.24 & 0.6516 & 0.15 & 0.7829 & -0.21 & 0.6949 & -0.06 & 0.9087 \\
\hline \multicolumn{9}{|l|}{ IRG (cycle 2) and DRG $(n=8)$} \\
\hline Cumulative utilization mean & - & - & - & - & - & - & 0.07 & 0.8676 \\
\hline Heterogeneity & - & - & - & - & 0.07 & 0.8676 & - & - \\
\hline Size & - & - & - & - & -0.13 & 0.7651 & 0.86 & 0.0064 \\
\hline Stocking density & - & - & - & - & -0.03 & 0.9531 & -0.59 & 0.1258 \\
\hline
\end{tabular}

${ }^{1}$ Mean absolute value of deviations of quadrat estimates from their paddock means. 
paddocks in intensity $\left(F_{7,1778}=221.70, P<0.0001\right)$ and heterogeneity $\left(F_{7,1778}=88.29, P<0.0001\right)$ of utilization, which were not correlated with forage availability or heterogeneity. Use was very light in all six paddocks representing the first of two IRG cycles. In the three paddocks where grazing occurred later (B of each treatment), intensity of use was higher and similar to that in the early-grazed DRG paddock (A), which was much lighter than in the late-grazed DRG paddock (B). There was not a consistent response in heterogeneity of use to the paddock size and stocking density gradient within the IRG paddocks, which were, with one exception, more evenly grazed than the DRG paddocks. The heavily used, late-grazed DRG paddock was grazed slightly more evenly than the other 70-ha paddock. The 1-ha paddock B was as unevenly used as the early-grazed DRG paddock, probably because it was grazed later than the other IRG paddocks and had some patches of prior use by a few horses that used the surrounding area very lightly but season-long.

Correlation between intensity and heterogeneity of use was strong within the IRG paddocks, but not when the DRG paddocks are included (Table 2); heterogeneity of use increased with intensity of use as long as intensity was light, but then decreased in the moderately utilized, late-grazed DRG paddock B. There was no correlation between utilization heterogeneity and paddock size within the IRG paddocks, but when the 70-ha DRG paddocks are included, the correlation approaches significance $(r=0.56, P=0.1514)$, and if the one outlier (1ha paddock B) is removed, it becomes significant $(r=0.82$, $P=0.0254$ ). There was no correlation with stocking density, however, because there was a greater difference between the DRG and IRG treatments on the scale of size than that of stocking density. Thus paddock size may have influenced heterogeneity of utilization at a larger scale (between grazing systems) than intensity of use, which drove heterogeneity within the IRG paddocks.

\section{Summer 2001 First Grazing Cycle}

Available forage per hectare was higher (except in 1-ha paddock A) and more similar between IRG paddocks for the first grazing cycle in 2001 than in 2000 (Table 1). Significant differences between paddocks $\left(F_{6,133}=3.51, P=0.0030\right)$ were primarily due to lower biomass in the new 1-ha paddock C. There were also significant differences in heterogeneity of forage available $\left(F_{6,133}=9.68, P<0.0001\right)$.

There were significant differences between paddocks in intensity $\left(F_{8,1846}=20.79, P<0.0001\right)$ and heterogeneity of utilization $\left(F_{8,1846}=48.16, P<0.0001\right)$. The IRG paddocks, although used more lightly, were all used more evenly than the DRG paddocks; differences within only the IRG treatments were slight and did not follow the treatment gradient. These results are clearer than those for the previous year, partly because the 1-ha paddock B was not an outlier in 2001 (when it was grazed earlier in the season and without the unintended effect of the horses).

As in 2000, heterogeneity of use in IRG paddocks was not correlated with the amount or heterogeneity of forage per hectare (Table 2). The correlations with paddock size and timing were strong if both systems are considered, but not for the IRG paddocks alone; correlation with stocking density was weaker. Heterogeneity of use was strongly correlated with intensity, indicating that patchiness of use increased as utilization increased. This relationship was even stronger than that with paddock size.

After one cycle in the IRG paddocks in both 2000 and 2001, there was no consistent response among the IRG paddocks to the paddock size and stocking density gradient. However, utilization heterogeneity after the first of two grazing cycles in all but one trial for small IRG paddocks was lower than after an entire season of grazing in large DRG paddocks.

\section{Summer 2001 Second Grazing Cycle}

There was less forage available in each IRG paddock at the beginning of the second grazing cycle (Table 1) than at the beginning of the first grazing cycle due not only to first cycle utilization, but also to other factors such as senescence and wildlife (including grasshopper) use. Forage available for the second grazing cycle was only $64-94 \%$ of that which remained after the first grazing cycle, based on utilization estimates. Significant differences between paddocks remained for standing forage $\left(F_{5,114}=3.34, P=0.0074\right)$ and heterogeneity of forage availability $\left(F_{5,114}=12.28, P<0.0001\right)$, but were not related to the treatment gradient.

Cumulative utilization differed across all paddocks $\left(F_{7,1757}=5.66, P<0.0001\right)$ and was positively correlated with forage heterogeneity prior to the first but not second grazing periods. There were significant differences in heterogeneity of cumulative utilization between paddocks $\left(F_{7,1757}=18.19\right.$, $P<0.0001$ ), but the clear pattern of the first cycle faded. The heterogeneity in the IRG paddocks increased to about the level of the early-grazed DRG paddock, but was less than in the lategrazed DRG paddock.

As in the first cycles, the correlation between heterogeneity of cumulative utilization and paddock size was strong when both systems are considered, but not among the IRG paddocks only; correlation with stocking density was weaker (Table 2). Heterogeneity of utilization was not correlated with mean utilization, either within IRG or across both systems, indicating that the relationship noted in the first cycles was no longer important after a full season of grazing.

The proportion of quadrats with no utilization after the full 2001 season was much lower in all of the IRG paddocks than in either of the DRG paddocks. The proportions are not statistically comparable because the quadrat sizes were unequal, but if the quadrat size used in the DRG paddocks had been the same $0.25 \mathrm{~m}^{2}$ used in the IRG paddocks, instead of $1 \mathrm{~m}^{2}$, the difference would be even greater because the smaller quadrat size would increase the proportions of extreme (that is, no or heavy use) observations.

\section{DISCUSSION}

The null hypothesis that grazing distribution in this study would be unaffected by reducing paddock size and increasing stocking density is rejected. In 2000, five of six, and in 2001, seven of seven small paddocks representing IRG after the first of two grazing cycles were grazed more evenly than two large DRG paddocks after the entire season of grazing. The advantage of IRG in evenness of use weakened after the second 
cycle in 2001, when the cumulative grazing intensities of all paddocks were equal. However, the lower proportions of unutilized quadrats in the IRG paddocks than in the larger DRG paddocks is consistent with Norton's (1998) hypothesis that livestock in smaller paddocks or at higher stocking densities tend to be more evenly distributed, such that the forage actually encountered, and thus available to animals, is increased.

All of the paddocks were fairly evenly grazed, although not to the degree reported by Hacker et al. (1988) across a narrower size range (1-8 ha). Even the 70-ha DRG paddocks are substantially smaller than most commercial paddocks, and the somewhat patchy distribution in these paddocks is not considered severe. This finding supports Norton's (1998) hypothesis that grazing studies on research stations have failed to show an advantage to IRG over extensive grazing management due to small paddock size and thus even distribution in all treatments (Hacker et al. 1988, BurboaCabrera et al. 2003). Similarly, Hart et al. (1989, 1993a) found that distribution was more even (and cattle gains were higher) in 24-ha paddocks whether they were grazed continuously or under eight-paddock SDG, than in a long and narrow 207-ha paddock with water at one end. They concluded that the improvement in distribution was due entirely to paddock subdivision and proximity to water, and not to rotation or stocking density. However, all research paddocks were smaller than most commercial paddocks, and stocking rates $>30 \%$ above the recommended rate for the area were used to attain approximately $50 \%$ utilization in 9-ha paddocks on the study area (Hart et al. 1988). Greater differences would be likely at a larger scale, where stocking density may become more important (Earl and Jones 1996; Teague and Dowhower 2003; Teague et al. 2004; Jacobo et al. 2006). Differences between grazing systems would also be more pronounced on ranges where severely grazed patches are perpetuated from year to year, such as those grazed yearlong, especially where there is a mixture of warm- and cool-season grasses and thus long growing seasons (Anderson 1988; Teague and Dowhower 2003; Teague et al. 2004).

The study design would have yielded a stronger test of the hypothesis if the grazing periods in the IRG paddocks had been twice as long, representing a one-cycle rather than a two-cycle rotation, thus removing grazing intensity as a confounding factor in comparison with the DRG paddocks. Moreover, due to the lack of regrowth after the first grazing periods, there was no reason for a two-cycle rather than a one-cycle rotation. The results might have been different had the study not occurred during a multiple-year drought, as weather is a dominating influence (Teague et al. 2004). The lack of a stronger difference between grazing systems at the end of the second season is likely due to the arbitrary grazing schedule and is consistent with reports by Anderson (1988) and Jacobo et al. (2006) of better distribution when grazing periods were timed according to plant growth rates than with calendar-based rotation or CG, respectively. Also, time control was necessary to maintain cattle gains in rotational grazing relative to CG or DRG (Hart et al. 1988, 1989). These findings collectively support the contention that timing of grazing periods according to plant growth rates is of central importance to the success of SDG (Savory 1983; McCosker 1994), and that many failures associated with SDG may have been due to not slowing down the rate of rotation during slow or no growth to provide for a nongrazing interval long enough for complete recovery (Savory with Butterfield 1999). Arid lands require longer recovery periods (Heitschmidt and Taylor 1991), often a year or more (Bradford 1998; Howell 2006). Uniformity of use in other rotational grazing studies may have been reduced by calendar-based, multiplecycle rotation (Kirby et al. 1986; Burboa-Cabrera et al. 2003), or by insufficient recovery periods (e.g., 2 mo during dormancy) even when the rotation was flexible (Bryant et al. 1989; Walker et al. 1989).

Heterogeneity of use was positively correlated with intensity of use in the IRG paddocks at half of the grazing for the season, but not at full grazing for the season, when the DRG paddocks were included in the analysis. Thus heterogeneity of use increased with intensity when utilization was light, and decreased when utilization was moderate; and when utilization was light, intensity of use had a stronger relationship with heterogeneity of use than did paddock size, but otherwise intensity of use was less important than paddock size. These results and the lack of correlation between paddock size and utilization intensity contrast with the findings of Hacker et al. (1988), which were attributed to behavioral differences with herd size (as few as three animals).

Another inconsistent but relevant factor was the time of season when grazing occurred. Utilization of IRG paddocks was more even after one early cycle than in DRG paddocks, but became more uneven after the second cycle in 2001. However, in 2000 the early-grazed DRG paddock was more unevenly grazed than the heavily used, late-grazed DRG paddock. Thus it seems that the seasonal timing of grazing was a factor in heterogeneity of utilization, but was less important than paddock size, stocking density, and utilization intensity. Timing is another possible reason for differences between our results and those of Hacker et al. (1988), who found only minor differences in heterogeneity of use between paddock sizes when all paddocks were grazed for 16 days in the spring.

Heterogeneity of utilization was not correlated with amount or heterogeneity of forage availability. This finding does not support the hypothesis of Walker et al. (1989) that grazing distribution is more sensitive to available forage than to grazing pressure or stocking density. That is more likely to be the case under more extensive grazing management, and at the larger scale of plant communities than patches. Use was heavier in open grasslands than in the understory of aspen or oak woodlands, regardless of grazing system (Barnes 2002), consistent with the finding of Walker et al. (1989) at the community scale.

There was also a weak tendency for locations within all paddocks to be used similarly in 2000 and 2001 (Barnes 2002), consistent with reports of grazed patches perpetuating across years (Willms et al. 1988; Ganskopp and Bohnert 2006). These interrelated patterns collectively demonstrate that distribution of utilization is nonrandomly heterogeneous at patch and community scales (Senft et al. 1987; Coughenour 1991; Bailey et al. 1996; Launchbaugh and Howery 2005), consistent with the ideas of patch grazing (Ring et al. 1985; Willms et al. 1988; Fuls 1992), and can be affected by grazing management (Bailey et al. 1996; Teague and Dowhower 2003; Bailey 2005). 


\section{MANAGEMENT IMPLICATIONS}

Although the inability to select paddocks randomly in this study prevents extrapolation to all paddocks everywhere, the difference between systems in this study implies that animal distribution can be improved by switching from extensive to intensive grazing management, but that improvement under IRG is not automatic and depends on how well the system is planned, and how adaptively the system, particularly the aspect of time control, is managed. Thus producers should expect a lag in production while managers and livestock learn and adjust to the new method (Anderson 1988; Hart et al. 1988, 1989; Olson and Malechek 1988). The optimal number or size of paddocks, stocking density, and length of grazing and recovery periods will vary widely with site, time, and management objectives. The economic benefits reported for IRG (Savory and Parsons 1980; Heitschmidt et al. 1990; McCosker 1994; Sayre 2000) are possible if the system increases the sustainable stocking rate without sacrificing individual animal production (Wilson et al. 1987), which is likely with dramatic improvement in spatial distribution (Norton 1998). The spatial benefits of rotational grazing may be partly realized through methods other than intensive fencing, including rotating access to water sources (Martin and Ward 1970), strategic supplementation (Bailey and Welling 2007), herding (Bradford 1998; Coughenour 1991; Butler 2000; Bailey 2005; Bailey et al. 2008), and manipulating animal behavior (Provenza 2003; Launchbaugh and Howery 2005), including selecting individual animals based on where they forage (Bailey et al. 2006).

Traditional grazing management has been articulated as a problem primarily of stocking rate and season (e.g., Holechek et al. 1999, 2003). Much of the IRG literature has focused on frequency of defoliation (e.g., Savory and Parsons 1980; Savory 1983; Savory with Butterfield 1999). This study shows that grazing management should be articulated in terms of managing spatial distribution as well as stocking rate, season, and frequency (Bailey et al. 1996; Bailey 2005). As such it supports the general ideas of Norton (1998), but not the hypothesis that time control becomes less important as stocking density and rate of rotation increase. Previous grazing studies may have found no advantage to intensive over extensive management because spatial heterogeneity was ignored or controlled for with small paddocks, or because recovery periods were insufficient. Future grazing management research should be done at a larger scale, in full commercial-size paddocks, and should separate the effects of paddock size, stocking density, and length of grazing and nongrazing periods, which should be adjusted to plant growth rates rather than calendar-based.

\section{ACKNOWLEDGMENTS}

The authors thank Dr. Ken Olson for assistance throughout the project, including reviewing an earlier draft of the manuscript. Susan Durham provided guidance with statistical analysis. Lee Wood, Morgan Christiansen, Andrew Ballard, Doug Vogel, Jim Bowns, Elizabeth Didier, and Seth Ohms assisted with the fieldwork. Keith Owens, Michael Smith, and two anonymous reviewers provided comments that improved the manuscript.

\section{LITERATURE CITED}

AndeRSON, D. M. 1988. Seasonal stocking of tobosa managed under continuous and rotation grazing. Journal of Range Management 41:78-83.

BAILEY, D. W. 2005. Identification and creation of optimum habitat conditions for livestock. Rangeland Ecology \& Management 58:109-118.

Bailey, D. W., J. E. Gross, E. A. Laca, L. R. Rittenhouse, M. B. Coughenour, D. W. Swift, And P. L. Sims. 1996. Mechanisms that result in large herbivore distribution patterns. Journal of Range Management 49:386-401.

Bailey, D. W., H. C. Vanwagoner, and R. Weinmeister. 2006. Individual animal selection has the potential to improve uniformity of grazing on foothill rangeland. Rangeland Ecology \& Management 59:351-358.

Bailey, D. W., H. C. Vanwagoner, R. Weinmeister, and D. Jensen. 2008. Evaluation of low-stress herding and supplement placement for managing cattle grazing in riparian and upland areas. Rangeland Ecology \& Management 61: 26-37.

Bailey, D. W., and G. R. Welling. 2007. Evaluation of low-moisture blocks and conventional dry mixes for supplementing minerals and modifying cattle grazing patterns. Rangeland Ecology \& Management 60:54-64.

BARNES, M. K. 2002. Spatial distribution of grazing on a gradient of paddock size and stocking density [thesis]. Logan, UT, USA: Utah State University. $63 \mathrm{p}$.

Bowns, J. E., and C. F. Bagley. 1986. Vegetation responses to long-term sheep grazing on mountain ranges. Journal of Range Management 39: 431-434.

BRADFORD, D. 1998. Holistic resource management in the West Elks-why it works. Rangelands 20(1):6-9.

Briske, D. D., J. D. Derner, J. R. Brown, S. D. Fuhlendorf, W. R. Teague, K. M. Havstad, R. L. Gillen, A. J. Ash, and W. D. Willms. 2008. Rotational grazing on rangelands: reconciliation of perception and experimental evidence. Rangeland Ecology \& Management 61:3-17.

Bryant, F. C., B. E. Dahl, R. D. Pettit, and C. M. Britton. 1989. Does short-duration grazing work in arid and semiarid regions? Journal of Soil and Water Conservation 44:290-296.

Burboa-Cabrera, F. R., W. H. Schacht, and B. E. Anderson. 2003. Utilization and grazing distribution of cattle at 4 stocking densities. Journal of Range Management 56:328-333.

ButleR, P. J. 2000. Cattle distribution under intensive herded management. Rangelands 22(2):21-23.

Coughenour, M. B. 1991. Spatial components of plant-herbivore interactions in pastoral, ranching, and native ungulate ecosystems. Journal of Range Management 44:530-542.

Cumming, K. J. 1989. Lehmann lovegrass and simple time control grazing. Rangelands 11:150-153.

EarL, J. M., And C. E. Jones. 1996. The need for a new approach to grazing management-is cell grazing the answer? Rangeland Journal 18:327-350.

FuLs, E. R. 1992. Ecosystem modification created by patch-overgrazing in semiarid grassland. Journal of Arid Environments 23:59-69.

Galt, D., F. Molinar, J. Navarro, J. Joseph, and J. Holechek. 2000. Grazing capacity and stocking rate. Rangelands 22(6):7-11.

Gammon, D. M. 1978. A review of experiments comparing systems of grazing management on natural pastures. Proceedings of the Grassland Society of Southern Africa (13th); 24-26 January 1978; Bloemfontein, South Africa. p. 75-82.

Gammon, D. M. 1984. An appraisal of short duration grazing as a method of veld management. Zimbabwe Agricultural Journal 81:59-64.

GansKopp, D., AND D. BohneRt. 2006. Do pasture-scale nutritional patterns affect cattle distribution on rangelands? Rangeland Ecology \& Management 59:189-196.

Gordon, K. 2002. An eye for grass: SRM bestows Oklahoma couple with "Outstanding Grazing Lands Managers" award. Rangelands 24(3):3-5.

Hacker, R. B., B. E. Norton, M. K. Owens, and D. O. Frye. 1988. Grazing of crested wheatgrass, with particular reference to effects of pasture size. Journal of Range Management 41:73-78.

Hart, R. H., J. Bissio, M. J. Samuel, and J. W. Waggoner, JR. 1993a. Grazing systems, pasture size, and cattle grazing behavior, distribution and gains. Journal of Range Management 46:81-87. 
HaRt, R. H., S. Clapp, and P. S. Test. 1993b. Grazing strategies, stocking rates, and frequency and intensity of grazing on western wheatgrass and blue grama. Journal of Range Management 46:122-126.

HaRt, R. H., M. J. Samuel, P. S. Test, and M. A. Smith. 1988. Cattle, vegetation, and economic responses to grazing systems and grazing pressure. Journal of Range Management 41:282-286.

Hart, R. H., M. J. Samuel, J. W. Waggoner, JR., and M. A. Smith. 1989. Comparison of grazing systems in Wyoming. Journal of Soil and Water Conservation 44:344-347.

Heitschmidt, R. K., J. R. Conner, S. K. Canon, W. E. Pinchak, J. W. Walker, and S. L. Dowhower. 1990. Cow/calf production and economic returns from yearlong continuous, deferred rotation, and rotational grazing treatments. Journal of Production Agriculture 3:92-99.

Heitschmidt, R. K., S. L. Dowhower, and J. W. Walker. 1987. Some effects of a rotational grazing treatment on quantity and quality of available forage and amount of ground litter. Journal of Range Management 40:318-321.

Heitschmidt, R. K., and C. A. TaYlor. 1991. Livestock production. In: R. K. Heitschmidt and J. W. Stuth [EDS.]. Grazing management: an ecological perspective. Portland, OR, USA: Timber Press. p. 161-177.

Holechek, J. L., H. Gomes, F. Molinar, D. Galt, and R. Valdez. 2000. Short duration grazing: the facts in 1999. Rangelands 22(1):18-22.

Holechek, J. L., H. Gomez, F. Molinar, and D. Galt. 1999. Grazing studies: what we've learned. Rangelands 21(2):12-16.

Holechek, J. L., R. D. Pieper, and C. H. Herbel. 2003. Range management: principles and practices. 5th ed. Upper Saddle River, NJ, USA: Prentice Hall. 624 p.

HowelL, J. 2006. On Twin Creek Ranch-acting on "change requests" in the sagebrush steppe. In Practice 109:8-9.

Jacobo, E. J., A. M. Rodríguez, N. Bartoloni, and V. A. Deregibus. 2006. Rotational grazing effects on rangeland vegetation at a farm scale. Rangeland Ecology \& Management 59:249-257.

Joseph, J., F. Molinar, D. Galt, R. Valdez, and J. Holechek. 2002. Short duration grazing research in Africa. Rangelands 24(4):9-12.

KIRBY, D. R., M. F. Pessin, and G. K. Clambey. 1986. Disappearance of forage under short duration and seasonlong grazing. Journal of Range Management 39:496-500.

Kothmann, M. M. 1980. Integrating livestock needs to the grazing system. In: K. C. McDaniel and C. D. Allison [EDS.]. Grazing management systems for Southwest rangelands; 1-2 April 1980; Albuquerque, NM, USA. Las Cruces, NM, USA: New Mexico State University, Range Improvement Task Force. p. 65-83.

Kothmann, M. M. 1984. Concepts and principles underlying grazing systems: a discussant paper. In: National Research Council [ED.]. Developing strategies for rangeland management. Boulder, CO, USA: Westview Press. p. 903-916.

Launchbaugh, K. L., and L. D. Howery. 2005. Understanding landscape use patterns of livestock as a consequence of foraging behavior. Rangeland Ecology \& Management 58:99-108.

Maeno, M. 2002. Effects of stocking density on species selectivity under rotational grazing systems [thesis]. Logan, UT, USA: Utah State University. $79 \mathrm{p}$

Martin, S. C., and D. E. Ward. 1970. Rotating access to water to improve semidesert cattle range near water. Journal of Range Management 23:22-26.

McCoskeR, T. 1994. The dichotomy between research results and practical experience with time control grazing. Australian Rural Science Annual 1994:26-31.

NoRTon, B. E. 1998. The application of grazing management to increase sustainable livestock production. Animal Production in Australia 22:15-26.

Norton, B. E. 2003. Spatial management of grazing to enhance both livestock production and resource condition: a scientific argument. In: N. Allsopp, A. R. Palmer, S. J. Milton, K. P. Kirkman, G. I. H. Kerley, C. R. Hurt, and
C. J. Brown [eds.]. Proceedings of the 7th International Rangeland Congress; 26 July-1 August 2003; Durban, South Africa. p. 810-820.

O'Connor, T. G. 1992. Patterns of plant selection by grazing cattle in two savanna grasslands: a plant's eye view. Journal of the Grassland Society of Southern Africa 9:97-104.

OLSON, K. C., AND J. C. MaleCheK. 1988. Heifer nutrition and growth on short duration grazed crested wheatgrass. Journal of Range Management 41:259-263.

Pechanec, J. F., and G. D. Pickford. 1937a. A comparison of methods used in determining percentage utilization of range grasses. Journal of Agricultural Research 54:753-765

Pechanec, J. F., and G. D. Pickford. 1937b. A weight estimate method for the determination of range or pasture production. Journal of the American Society of Agronomy 29:894-904.

Pieper, R. D. 1980. Impacts of grazing systems on livestock. In: K. C. McDaniel and C. D. Allison [EDS.]. Grazing management systems for Southwest rangelands; 1-2 April 1980; Albuquerque, NM, USA. Las Cruces, NM, USA: New Mexico State University, Range Improvement Task Force. p. 133-152.

ProvenZA, F. D. 2003. Foraging behavior: managing to survive in a world of change. Logan, UT, USA: Utah State University, Department of Forest, Range, and Wildlife Sciences. $63 p$.

Ring, C. B., A. Nicholson, and J. L. Launchbaugh. 1985. Vegetational traits of patchgrazed rangeland in west-central Kansas. Journal of Range Management 38:82-87.

SAS [Computer PRogram]. 1999. Version 8. Cary, NC, USA: SAS Institute Inc.

SAVORY, A. 1983. The Savory grazing method or holistic resource management. Rangelands 5:155-159.

Savory, A., AND with J. Butterfield. 1999. Holistic management: a new framework for decision making. 2nd ed. Washington, DC, USA: Island Press. $616 p$

Savory, A., and S. Parsons. 1980. The Savory grazing method. Rangelands 2:234-237.

SaYre, N. F. 2000. The new ranch handbook: a guide to restoring Western rangelands. Santa Fe, NM, USA: Quivira Coalition. 102 p.

Senft, R. L., M. B. Coughenour, D. W. Balley, L. R. Rittenhouse, O. E. Sala, and D. M. SwIFt. 1987. Large herbivore foraging and ecological hierarchies. BioScience 37:789-799.

Soltero, S., F. C. Bryant, and A. Melgoza. 1989. Standing crop patterns under short duration grazing in northern Mexico. Journal of Range Management 42:20-21.

Teague, W. R., And S. L. Dowhower. 2003. Patch dynamics under rotational and continuous grazing management in large, heterogeneous paddocks. Journal of Arid Environments 53:211-229.

Teague, W. R., S. L. Dowhower, and J. A. Waggoner. 2004. Drought and grazing patch dynamics under different grazing management. Journal of Arid Environments 58:97-117.

Vallentine, J. F. 2001. Grazing management. 2nd ed. San Diego, CA, USA: Academic Press. 659 p.

Walker, J. W., R. K. Heitschmidt, and S. L. Dowhower. 1989. Some effects of a rotational grazing treatment on cattle preference for plant communities. Journal of Range Management 42:143-148.

Willms, W. D., J. F. Dormaar, and G. B. SchaalJe. 1988. Stability of grazed patches on rough fescue grasslands. Journal of Range Management 41:503-508.

WILSON, A. D. 1986. Principles of grazing management systems. In: P. J. Joss, P. W. Lynch, and O. B. Williams [EDS.]. Rangelands: a resource under siege. Proceedings of the 2nd International Rangeland Congress; 13-18 May 1984; Adelaide, South Australia. Canberra, Australian Capital Territory: Australian Academy of Science. p. 221-225.

Wilson, P. N., D. E. Ray, and G. B. Ruyle. 1987. A model for assessing investments in intensive grazing technology. Journal of Range Management 40:401-404. 